\title{
Volhynian Revolution or Emergence of Conspiracy Theories in the Borderlands of the Russian Empire
}

\author{
K. B. Egorova
}

For citation: Egorova K. B. Volhynian Revolution or Emergence of Conspiracy Theories in the Borderlands of the Russian Empire. Vestnik of Saint Petersburg University. History, 2020, vol. 65, issue 3, pp. 710-720. https://doi.org/10.21638/11701/spbu02.2020.302

This article is devoted to the issue of the emergence of conspiracy theories and their existence in the borderlands; the research is focused on the western boundaries of the Russian Empire, belonging to the Polish-Lithuanian Commonwealth before its partition. The material relating to these territories enables to have a fresh look on genesis of "the conspiracy theories" in society, on the one hand, to reflect on the peculiarity of the borderland as a special cultural space, and, on the other hand, to add specific characteristics of "conspiracy theories" of the borderlands to the list of contributory factors to emergence of conspiracy theories in society. Reference to the west borders of the Russian Empire enables to use the material related to the beginning of $19^{\text {th }}$ century, which is important for further development of the conspiracy study in Russia. This article centers around the analysis of "The letters written by court counsillor Opytov to countess Starozhilova with historical overview of the political mood of the nobility in Volhynian governorate". Life of Volhynian Governorate at the beginning of the $19^{\text {th }}$ century is reflected in the letters which contain the exposure of the Polish gentry's plot against the Russian stateness. The extent of the "historicity" of this document and the possibility of assessing the situation in this region based on so-called Opytov's evidence raise doubts. The performed analysis shows that Opytov's letter was a fiction aimed at a narrow circle of readers familiar with the situation in Volhynia and western regions in general. The text of this letter contains the encrypted conspiracy narratives, known to Opytov's contemporaries, which can become the key to understanding what type of text it is.

Keywords: conspiracy theories, history of Russian Empire, borderlands theory, polish history and culture.

\section{Волынская революция или Возникновение конспирологических теорий на границах Российской империи}

\section{К. Б. Егорова}

Для цитирования: Egorova K. B. Volhynian Revolution or Emergence of Conspiracy Theories in the Borderlands of the Russian Empire // Вестник Санкт-Петербургского университета. История. 2020. Т.65. Вып. 3. С.710-720. https://doi.org/10.21638/11701/spbu02.2020.302

Данная статья посвящена проблеме возникновения и бытования конспирологических теорий на пограничных территориях. В центре исследовательского внимания на-

Kseniia B. Egorova - PhD in Philology, Deputy Director, St. Petersburg Department of Russian Geographic Society, 10, per. Grivcova, St. Petersburg, 196195, Russian Federation; xenia.egorova@gmail.com

Ксения Борисовна Егорова - канд. филол. наук, заместитель директора по научной работе, Штаб-квартира Русского географического общества в Санкт-Петербурге, Российская Федерация, 196195, Санкт-Петербург, пер. Гривцова, 10; xenia.egorova@gmail.com

() Санкт-Петербургский государственный университет, 2020 
ходятся западные границы Российской империи, принадлежавшие Речи Посполитой до ее разделов. Материал, относящийся к этим территориям, позволяет по-новому взглянуть на генезис «теорий заговора» в обществе, поразмышлять, с одной стороны, о специфике пограничья как особого культурного пространства, а с другой - дополнить имеющийся у нас список факторов, формирующих конспирологические настроения в обществе, включив в него специфические характеристики пограничных «теорий заговора». Обращение к западным границам Российской империи позволяет привлечь материал, относящийся к началу XIX в., что немаловажно для дальнейшего развития изучения конспирологии в России. В статье дается анализ конспирологических нарративов о заговоре польской шляхты на территории Волыни в начале XIX в. Материалом для подробного анализа стали «Письма надворного советника Опытова гр. Старожиловой с историческим обзором политических настроений дворянства Волынской губернии». Все три письма повествуют о настроениях польской шляхты в Волынской губернии. Опытов совершил многодневное путешествие по Волыни, конечным пунктом его назначения являлась Вена (если мы проследим маршрут, то отметим, что направился он не по прямой дороге из Житомира в Вену, но кружил по губернии, заезжая в различные города, которые находятся в большом отдалении друг от друга). Путешественник собирал различные сведения, которые, по его мнению, могли касаться заговора польской шляхты. Степень «историчности» этого документа, а значит, и возможности строить какие-либо предположения о ситуации в указанном регионе на основе так называемых свидетельств Опытова вызывают сомнения. Проведенный анализ показывает, что письмо Опытова являлось литературным произведением, предназначенным для узкого круга читателей, знакомых с ситуацией на Волыни и в западных областях в целом. В тексте данного письма зашифрованы известные современникам Опытова конспирологические нарративы, которые могут стать ключом к пониманию, какого типа текст перед нами.

Ключевые слова: конспирологические теории, история Российской империи, история пограничий, польская культура.

As a rule, researchers ${ }^{1}$ of "the conspiracy theory" point out mistrust of existing political and social structure, state power and power as such among the factors determining the emergence and development of the conspiracy theories in society. Conspiracy theories in the society are also strongly influenced by a human desire for a simplified and popular explanation of the complicated political and historical events as well as by the degradation of public and state institutions ${ }^{2}$.

All these conclusions about the genesis of conspiracy narratives and their distribution within the society as explanatory models of ambiguous social and political events are supported by extensive empirical data; however, it seems necessary to widen the materials' spectrum used by researchers of "the conspiracy theory" as well as to shift the focus of the attention from studying "Jewish", "Masonic", "Jewish-Masonic" conspiracies, American government theories inspired by cult series "The X-files" to other objects that will enable to clarify our theoretical models about the emergence of the idea of conspiracy and its existence in the Russian history. Ideas proposed by foreign scholars who mainly focused

1 The principal works on this issue belong to Y.R. Biberstein, L. Boltanski, D. Pipes, M. Fenster. We should mention the following national researchers of conspiratorial narratives - A. L.Zorin, L. D. Gudkov, M.D. Dolbilov and M. V. Khlebnikov. The works of the mentioned national and foreign researchers were used as a theoretical basis of this article.

${ }^{2}$ More on this: Bibershtayn Y.R. Mif o Zagovore: filosofy, masony, evrei, liberaly i sotsialisty v roli zagovorshchikov. St. Petersburg, 2010. P. 12. 
on the material available in their country should be adjusted to the analysis of Russian conspiracy plots ${ }^{3}$.

A small number of publications examining Russian history and culture, and the prevalence of researches in English distort the picture of the existence of conspiracy theories here; geography of their development and distribution seems more local; Russia and Eastern Europe, due to significant research gaps in analysis of conspiracy narratives emerged on these territories, may erroneously appear as recipient societies incapable of producing their own conspiracy theories and only accepting ready-made social panic models (from the Masonic conspiracy to the paranoid idea of taking over the world by extraterrestrial intelligence).

This article is devoted to the issue of the emergence of conspiracy theories and their existence in the borderlands; the research is focused on the western boundaries of the Russian Empire, belonging to the Polish-Lithuanian Commonwealth before its partition. The material relating to these territories enables to have a fresh look on genesis of "the conspiracy theories"' in society, on the one hand, to reflect on the peculiarity of the borderland as a special cultural space, and, on the other hand, to add specific characteristics of "conspiracy theories" of the borderlands to the list of contributory factors to emergence of conspiracy theories in society. Reference to the western borders of the Russian Empire enables to use the material related to the beginning of $19^{\text {th }}$ century, which is important for further development of the conspiracy study in Russia.

There is no doubt that the history and culture of the western borderlands of the Russian Empire attracts the attention of contemporary national and foreign researchers as these fields provide ample opportunities for historical, dialectological and cultural analysis of the material 4 . M.D.Dolbilov, a researcher of this cultural space, names "western outskirts of the Russian Empire" the main subject of his scholarly interest ${ }^{5}$. There is a theoretical approach established in numerous works to look at cultural and social life of the population of western borderlands as at peripheral regions and to apply a "dichotomy model" to their cultural and political processes ${ }^{6}$. That is why researchers consider the western borderlands of the empire among frontier regions included in the opposition to the center, capital culture and life ${ }^{7}$.

3 Thus, Gordon Arnold's work "Conspiracy theory in film, television, and politics" starts with the concept that conspiracy is almost the main thing, uniting and characterizing American mass culture (see: Gordon B. Arnold. Conspiracy Theory in Film, Television, and Politics. Westport; Connecticut, 2008. P. 1).

${ }^{4}$ See some works, touching upon the issue of former Polish territories in national and cultural politics of the Russian Empire: Beauvois D. Gordiev uzel Rossiiskoi imperii: Vlast', shliakhta i narod na Pravoberezhnoi Ukraine (1793-1914). Moscow, 2014; Vul'f L. Izobretaia Vostochnuiu Evropu: karta tsivilizatsii v soznanii epokhi Prosveshcheniia. Moscow, 2003; Poliaki i russkie v glazakh drug druga. Moscow, 2000; Zorin A. "Kormia dvuglavogo orla...": Literatura i gosudarstvennaia ideologiia v Rossii v poslednei treti XVIII - pervoi treti XIX v. Moscow, 2001.

${ }^{5}$ Dolbilov M., Miller A. Western outskirts of the Russian Empire. Moscow, 2007.

${ }^{6}$ Studying the outskirts of the Russian Empire as a specific phenomenon from the point of view of administrative management, the relationship between the center and the periphery has its own history and methodology. See: Dameshek L. M., Dameshek I. L. Poniatie "okrainy". Tipologicheskie skhodstva i razlichiia // Okrainy Rossiiskoy imperii: instituty i biurokratiia XIX — nachala XX vekov. Irkutsk, 2015. P. 6-29; Bakhturina A. Yu. Okrainy Rossiiskoy imperii: gosudarstvennoe upravlenie i natsional'naia politika v gody pervoi mirovoi voiny (1914-1917). Moscow, 2004; Okrainy Moskovskogo gosudarstva i Rossiiskoi imperii: innovatsionnye podkhody v izuchenii imperskoi istorii Rossii. Kazan', 2015.

7 See more about relationship between the periphery and the center as a special sphere of cultural interaction within the empire: Ab Imperio. 2012. No. 1 (cover story: Periphery as the center). 
Such an approach inevitably leads to the shift of the research attention from the issues of Western regions as the integral cultural and historical unity to the issues of relationship between the center of the Russian Empire and its numerous peripheries. Therefore, this approach can only partially be applicable to the objectives of this work as the idea of this article is to focus on the cultural and political life of the western borders of the Russian Empire as the integral space included not only in the "outskirts-center" dichotomy, but in the other research paradigms (for example, the "cultural borderland" theory).

The term "cultural borderland", reflecting the attitude to the territories it defines as a specific cultural integrity, a conglomerate of traditions, languages and literatures of all the peoples inhabiting it ${ }^{8}$, can be used to describe the western borders of the Russian Empire. The subject of this article (i.e. "the cultural borderlands") has its own name in Polish tradition ("kresy", "taken lands"). This term is used primarily for Volhynian governorate added to the Russian Empire after the Lithuanian-Polish Commonwealth partitions (Volhynian lands partially became part of Russia after the second partition in 1793; the Russian Empire took control over the entire Volhynian territory in 1795 after the third Poland's partition). Annexation of these lands caused the need to settle ethnic and linguistic conflicts between the population and the new tsarist administration in the borderlands. Traditionally, "kresy" in Russian and Polish researches relate to the "friend-or-foe" opposition and development of concept of "enemy image".

M.D. Dolbilov in his article "Polonofobiia i politika rusifikatsii v severo-zapadnom krae imperii v $1860 \mathrm{~g}$ " (Polonophobia and policy of Russification in the North-West of the Empire in the 1860s) ${ }^{10}$ explores the development of ethnic phobia and image of the Pole as enemy after the January uprising of 1863-1864. This study most closely approaches the issue related to formation and existence of the conspiracy theories in the former Polish regions. Thus, the author pays attention to the image of "an artful Polish woman as a symbol of hatred to Russia"11. The ethnic-national scope of the notion of "Pole" in his work is filled with political, social, confessional and even gender meanings. Dolbilov's observation has a great potential for studying this national stereotype in the context of hitherto conspiracy theories (for example, about the curse of Marina Mnishek). A. L. Zorin also turns

8 There is extended literature on the cultural borderlands' theory developed by American researchers. They are mainly focused on the issues of the USA and Mexico border. The first methodological grounds for referring the borderlands to specific area of studies were based on this material. The issues of the borderlands as a special cultural and historical space have been further comprehended; the first methodological practices were applied to other materials (mainly, the materials collected in the Eastern Europe were used: Polish-German, Polish-Belarusian, Polish-Ukrainian and others). See: Literature and Ethnicity in the cultural borderlands / ed. by J. Benito, A. M. Manzanas. Amsterdam, New York. 2002; Follis K. S. Building Fortress Europe. The Polish-Ukrainian Frontier. Philadelphia, University of Pennsylvania Press, 2012; Holm-Hansen $J$. Three perspectives on the borderland: The case of northeast Poland and the regions across the border // Pogranicze: Studia Społeczne / ed. by A. Sadowski. Białystok, 2000. Vol.9. P.95-113; The New Europe: Uncertain Identity and Borders / ed. by M.W. Kowalska. Białystok. 2007; Pawluczuk W. The Polish-Belarusian Frontier in the Civilization Context // The New Europe: uncertain identity and borders. Białystok. 2007. P. 141-146; Bobkov I. Etika pogranich'ia: transkul'turnost' kak belorusskii opyt // Perekrestki. 2005. No. 3-4; Breskiy O., Breskaya O. Ot tranzitologii k teorii pogranich'ia. Ocherki dekonstruktsii kontsepta "Vostochnaia Evropa". Vil'nus, 2008; Posle imperii: issledovanie vostochno-evropeyskogo pogranich'ia / ed. by I. Bobkova, S. Naumovoy, P. Tereshkovicha. Vil'nus, 2005.

9 Dolbilov M.D. Polonofobiia i politika rusifikatsii v severo-zapadnom krae imperii v $1860 \mathrm{~g}$. // Obraz vraga. Moscow, 2005. P. 127-174.

10 Ibid. P. 154.

11 Ibid. 
indirectly to the study of the image of "the enemy" in the context of politics of the Russian Empire and rightfully notes that "a Polish woman has become a symbol of temptation and danger in the Russian literature for many years"12. Zorin also points out that speculations about a crafty Polish woman as a symbol of the enemy could be caused by Polish origin of Maria Antonovna Naryshkina (née Princess Chetvertinskaia), an Alexander's I favorite ${ }^{13}$.

The life of Volhynian Governorate at the beginning of the $19^{\text {th }}$ century is reflected in "The letters written by court counselor Opytov to countess Starozhilova with historical overview of the political mood of the nobility in Volhynian governorate"14. The letters contain the exposure of the plot of the Polish gentry against the Russian stateness. One of the most authoritative studies in the history of the Right-Bank Ukraine ${ }^{15}$ considers Opytov's texts as a historical document. The author based his research on the unfinished copy of one of Opytov's letters kept at the Russian State Historical Archive and built the analysis of the political situation in western governorates grounding his point of view in this archive document ${ }^{16}$.

The French historian recounted in details the part of the letter kept in the Russian State Historical Archive to confirm his conclusions about a tense ethnic and political situation in Volhynian governorate after the Napoleonic wars: "Such friends of Komburlei ${ }^{17}$ as countess Starozhilova even asked the travelers secretly about the mood and wanted to know the details of Komburlei's resignation which, in their opinion, was caused by the Polish conspiracy. State counsillor Opytov ${ }^{18}$ readily confirmed these suggestions in his letter from Vienna, written in July 1818, i. e. at the time when the Russian conservative society was shocked by the Emperor's speech in Warsaw, in which he spoke about uniting "the former Polish governorates with the Kingdom of Poland"19.

The author decided to quote the content of the letter as he considered the document rare and unpublished, not being aware of the publication of all the letters in "Kievskaia Starina". It remains unclear why the French historian took countess Starozhilova for a real person ${ }^{20}$, a friend of Volhynian governor Mikhail Ivanovich Komburlei, and Opytov's letters - for the result of the countess's secret queries about the moods in those lands.

12 Zorin A. “Kormia dvuglavogo orla...”... P. 178.

13 Ibid.

14 All three letters were published in the magazine "Kievskaia Starina" under the general name "Volhynian Revolution in 1883" (in January, February and April). An unfinished copy of the first letter is kept in the Russian State Historical Archive (F.1101. Op. 1. D. 344. L. 1-4). This copy is stored in fund 1101, documents of personal origin that do not constitute separate funds, and presumably came from the collection of Ilya Ivanovich Krusnievski. The address calendar for 1823 and 1824 states that he served as a college secretary in Orel governorate. The data of 1101 list enables to make a conclusion that he corresponded with the nobles from the neighboring governorates (for example, with Grigory Fedorovich Gezelinsky, a collegiate councillor to Kharkov governorate). The unfinished copy of the letter of Opytov was made, presumably, by the hand of Krushevsky.

15 Beauvois D. Gordiev uzel Rossiiskoi imperii: Vlast', shliakhta i narod na Pravoberezhnoi Ukraine (1793-1914). Moscow, 2014.

${ }^{16} 1815$ integration issues: strictness in Podolye and magnanimity in Volyn lands // Beauvois D. Gordiev uzel Rossiiskoy imperii... P. 326-330.

17 Komburlei Michail Ivanovich (1761-1821) - Volyn governor (1806-1815).

18 Opytov calls himself a court counselor in the letter.

19 Beauvois D. Gordiyev uzel Rossiyskoy imperii... P.326.

20 The Collection of Kharkov Historical and Philological Society (vol. 13, Kharkov, 1902) provides a detailed and complete description of Khotensk archive (named after the place of documents' storage, Komburlei's country estate Khoten), where there was kept extensive business and personal Komburlei's correspondence. There was no mention of countess Starozhilova among the correspondents of the estate's owner. 
Other researchers also refer to Opytov's letter as a historical document allowing to make some conclusions about anti-Russian moods of the population of Volhynian governorate after the Napoleon's wars. For example, magazine "Otechestvennye Zapiski” (no. 5, 2012) published the article of A.Portnov "Poland obtained but not gained", which contained the quoted lines from Opytov's letter as a possible evidence by a contemporary about the Polish conspiracy.

The extent of "historicity" of this document and the possibility of drawing some conclusions about the situation in this region based on so-called Opytov's evidence raise doubts. The analysis shows that Opytov's letter was a fiction aimed at a circle of narrow readers familiar with the situation in Volhynia and western regions in general. The text of this letter contains the encrypted conspiracy narratives known to Opytov's contemporaries, which can become the key to understanding what type of the text it is.

The editor of "Kievskaia Starina" (in 1883, when the letters were published, the magazine was edited by Feofan Gavrilovich Lebedincev) entitled the series with an attractive phrase for a reader "Volhynian Revolution" and provided the text with a brief insight into the history of the publication. Lebedincev noted that he had received the letters from Vasilii Stepanovich Popov's son (secretary and confidant of Grigory Aleksandrovich Potemkin); to his mind, the letters constituted a part of so-called Reshetilovsk's archive (named after Popov's country estate Reshetilovka, where the richest library was stored). The editor carefully recorded that the author of the letters was disguised under a fictious name and suggested that the texts about so-called Volhynian revolution were popular at one time and circulated within a narrow circle of the like-minded people.

All three letters tell about the moods of the Polish gentry in Volhynian governorate. Opytov travelled a while around Volhynia, but his destination was Vienna (if we trace the route, we will notice that he took an indirect road from Zhitomir to Vienna, he skirted the governorate, visited different towns located far away from each other). The traveler collected various pieces of information, which, in his opinion, could relate to the conspiracy of the Polish gentry. In his last letter, Opytov wrote, "The information I have received from the court acts in Petersburg, the notes and reliable eyewitnesses' evidence I have collected in Volhynia, Brody and Lvov, will serve the basis for a fair narration and impartial declaration of the historical truth about Volhynian revolution..."21

Opytov's work resulted in the observations about the origin of the Polish gentry's conspiracy in Volhynia and mechanisms of its formation. We consider Volhynian revolution as a very prosaic event - the governorate's power struggle between Russian and Polish civilians. This struggle involves almost all heads of the noble families, who use different means to achieve the cherished goal - to overthrow the civilians who have come from the capital and to assert Polish dominance in the region. Before the eyes of Opytov a comedy of situations is played out: he observes flattery, insidiousness, vivid gestures and diversity of anecdotal stories. Mikhail Ivanovich Komburlei was the target of the conspiracy; he was to be overthrown. Opytov describes in details the conspiracy, herewith focusing on some of its most important elements: composition of conspirators, the subject, aims and plan of conspiracy.

Almost all known Polish families of the region are named in letters among the conspirators and their agents: "The voice of the people is the voice of God. We have the agents

${ }^{21}$ Volyn Revolution // Kievskaia Starina. 1883. February. P.313. 
in all districts. Honorable families: Worcels, Stroinovskii, Rziszewski, Gostynski, Stecki..."22 Opytov provided a rather significant list of the noble kins and mentioned that they "had sworn to sacrifice themselves and their property to ruin the Russian Empire and to recover Polish state" 23 , and that their aim was "to fuel their national hatred toward Russians"24. In Opytov's opinion, the conspirators have a rather clear plan and are capable of the coordinated actions. The conspiracy plan of the Polish gentry is as follows: "Gizhitskii ${ }^{25}$ shall immediately race to Volhynia and take up a post of the Governorate Marshal, try to use his agents to inflame people and provoke the Volynyans to all bold prejudices against Komburlei and his subordinates $\langle\ldots>$ Oginski shall write to his friends in Vilno and Warsaw about tension between general forces so that after Komburlei's overthrow, the Poles not Russians, could become governors and other civilians in all provinces annexed from Poland $<\ldots>$ Stroinovskii ${ }^{26}$ and Wortse ${ }^{27}$ shall make friends in all jurisdictions in the capital and in the Cabinet of Ministers, and carry on correspondence within Volhynia with their help; all the others in general, both by themselves and through their accomplices and secret spies, wherever it happens to anyone - at court, in the Senate, in the ministries, in houses of noble persons, in the clubs, at the meetings and during conversations, shall disperse rumors and assure with divine confidence that the heads of Volhynian governorate and Russian civilians allow terrible abuses..." ${ }^{28}$ According to Opytov, Polish landowners have their own methods to implement an insidious anti-Russian conspiracy: "Herewith you should speak up instead of using dull language of reason..."29

If we look for a wider context of the idea of Polish intrigue against the Russian stateness, we will find rich material for analysis. Michail Nikiforovich Katkov (1818-1887) in his well known among the contemporaries articles developed the basis for the Polish intrigue as a political force during the whole $19^{\text {th }}$ century and earlier. In his polemic articles published after the Polish uprising in 1863-1864 ("Coincidence of interests of Ukrainophiles with Polish interests", "Polish question", “To the issue of political arson”), Katkov introduced the diction used in the Polish context: conspirators, secret intention, secret intrigue, arsonists' gang. By the moment Opytovs' letters were published in "Kievskaia Starina”, the Russian society was prepared to understand the issue of Polish intrigue and the language describing it. The next important material to contribute to the context of appearance and reception of Volhynian letters was provided by Nikolai Ivanovich Pavlishchev (1801-1879), the editor and the author of the unpublished explanatory note about "Warsaw Diary" entitled "Polish Intrigue" and dated February 1870. Pavlishchev admitted the following: "The Polish intrigue acts indefatigably and systematically, both in exile and primarily in Galicia and Poznan. The Polish pens work in the most important editorial offices in Paris, Poznan and partly in Berlin. They publish the most obscene articles against

22 Volyn Revolution// Kievskaia Starina. April. P. 322.

23 Ibid. P. 323.

24 Ibid.

${ }^{25}$ Gizhitskii Varpholomei Kaetanovich (1775-1826) - Russian military and statesman, major general, actual state counsellor, Volyn governor (1816-1824).

${ }^{26}$ We mean Valerian Stroinovskii (1759-1834) - Polish economist, brother of famous student of law school Ieronim Stroinovskii (1752-1815).

27 Worcel Stanislaw Gabriel (1799-1857) - Polish social and political activist.

28 Volyn Revolution// Kievskaia Starina. 1883. April. P. 323.

29 Ibid. 
us..." ${ }^{30}$ Pavlishchev also mentions in this document that he works on the outskirts of the Empire; therefore, he sees the Polish intrigue more clearly. It is obvious that Pavlishchev's evidence does not directly point to basis of the conspiracy concerning his words about the Polish intrigue; but we can identify the fact that the editor of "Warsaw Diary" uses the "vocabulary of conspiracy" while describing the Poles' actions.

The image of a Polish betrayer of the Russians and the Russian (Orthodox) religion had been formed in the official and literature discourses of the Russian Empire for several centuries $\left(17^{\text {th }}-21^{\text {th }}\right)^{31}$. It is noticeable that in the $19^{\text {th }}$ century the notion of "a Polish betrayer" is reproduced in consistent context. A Polish betrayer is as an external as well as an internal enemy. "The Polish conspiracy" against the Orthodoxy and Russian people develops in two aspects: it includes a direct Polish expansion taking different forms (introduction of Catholicism, introduction of Uniatism, capture of Moscow by the Polish magnates, incitement to burn the Russian capital etc.); and treacherous, "subversive" activities within Russian society (for example, biography and literary fate of Faddei Bulgarin: his literary and social activities are often interpreted in connection with the idea of the Polish conspiracy aimed at destruction of Russia).

Opytov details with some irony examples of "subversive" activities of Volhynia inhabitants. The author uses many narratives emerged by the beginning of the $19^{\text {th }}$ century related to the secret subversive activities of the Poles in Russia. According to Opytov's interpretation, the inhabitants of Volhynia at the beginning of the $19^{\text {th }}$ century could be equated with all conspirators related to Volym region trying their best to undermine Russian stateness. "Volhynian governorate has been at all times known for its anti-Russian activities. In its districts..."32:

1. Korosten (Iskorosten). Grand Prince Igor was treacherously killed.

2. Kremenec. False Dmitry, unfrocked priest, began a rebellion against our Fatherland with the help of the Polish citizens; there were still the ruins of the church where he was married to Mnishek's daughter in Ostrog.

3. Novgorod-Volynsky and Starokonstantinov Uezd. Before the war with Hetman Khmelnitsky, the local landed gentry handed over to the Jews Greek-Russian churches for oppression of Orthodoxy.

4. Zhitomir. On the pretext of Gaidamachina, they put to death over ten thousand peasants.

5. Lutsk. When Poland was about to collapse, specially organized committees abused Russian subjects, killing our intellectuals and merchants and putting to death priests of the same confession.

6. Dubno. In 1794, the nobles who came for contracts from Great Poland, Lithuania and Galicia, decided who, where and how should act, and what the most traitorous way to exterminate all Russians in Poland.

7. Minor sins: sent the children outside the country "just to bear arms against the Russians"; mourned those who died in the Napoleon wars for a long time.

${ }^{30}$ RO IRLI. F. 572. D. 20. L. 1 ob.

31 The earliest materials go back to the end of the $16^{\text {th }}$ - beginning of the $17^{\text {th }}$ century (See: Sbornik dokumentov, uiasniaiushchikh otnoshenie latino-pol'skoi propagandy k russkoi vere i narodnosti. Vil'no, 1866).

32 RSHA. F. 1101. Op. 1. D. 344. L. 1. 
Opytov noted that all the crimes of the inhabitants of Volhynia "were covered up by the highest manifestos"; therefore, he would not disclose them anymore. This refers to the rumors that Emperor Alexander I showed too much mercy to the Polish betrayers, surrounded himself with Poles and wanted to recreate Poland in its former borders.

Opytovs' letter retells the history of Volhynia written in the most ironic form: a series of conspiracies uniting all the events from the early to modern times. We can compare this evidence with "Volhynian Notes" by Stepan Vasilievich Russov, a prosecutor of Volhynian Governorate in 1806, which appeared in $1809^{33}$. He was the first to present in Russian the history of this territory in details. He attempted to describe the way of life and traditions of the local population; the text included ethnographic notes; the episodes Opytov satirized had been described in "Volhynian Notes" as the evidence of the region's rich history. Thus, according to the "Notes", there were still the ruins of that church in Ostrog where Dmitry had been married to Mnishek's daughter. Russov described a continual mourning for the Poles killed in the war with Russia as a custom in this region, while Opytov saw it as manifestation of conspiracy and Russophobia of the locals. Plenty of such coincidences can be explained, in particular, by the fact that the real author of Volhynian letters was familiar with Russov's work.

It is hardly possible to identify the person who hid behind the pseudonym Opytov and who the author of the letters about Volhynian revolution was. The letters, as a fictional text written with irony and detailed knowledge of customs and administrative structure of the region, could have been written by Russov, the author of "Volhynian Notes" (the parallels between these two texts have been mentioned above). From 1806 to 1808, Russov served as court counsillor in Volhynian Governorate under command of Komburlei and held the post of the governorate prosecutor (we should note that Opytov had the same title $)^{34}$; he was aware of all administrative intrigues and could be present at the partiess in the houses of Russian and Polish gentry. The author of the letters frequently described such evenings and meetings as a direct participant of the event, familiar with each of the guests. Thus, in the first letter we can read the following anecdotal story from the daily life of Volhynian noble men: Opytov tells about one of the feast in the Romanovs Castle where a pretty drunk representative of the Polish gentry, Gizhitskii, imagined that he was fighting under Kostyushko's name and threw a glass in the head of the governor as the latter stood for the Russian Empire: "He grabbed the glass from the table and hit a poor governor in the forehead so hard that the latter fell off the chair and ensanguined the entire floor of the Romanovs Castle with his blood; the castle was decorated, as they said, with the furniture stolen from the Marble Palace"35.

The second and third letters contain a number of references to the case history of that time, sketches of different meetings of the author with the representatives of this administrative region. The mentioned facts enable us to make certain conclusions about a social

${ }^{33}$ Russov S. V. Volynskie zapiski, sochinennye v Zhitomire. St. Petersburg, 1809. - Later on the historian turned back to this topic and published the translation of Jan Potocki's book (1761-1815): The ancient history of Volyn governorate, which serves as a continuation of the Primeval History of the Peoples of the Russian State, composed by Count Ioann Potocki / ed. by S. Russov. St. Petersburg, 1829.

34 The information could be found in the Address calendars (1806-1808).

35 Volyn Revolution // Kievskaia Starina. 1883. February. P. 317. 
portrait of the author of the letters and suggest that it could have been Russov, who, among all, was a literary man, and his works were often published in press ${ }^{36}$.

Opytov's letters show a persistent narrative, according to which a global Polish conspiracy against the Russian stateness and Orthodox faith exists. We should assume that one of the specific features of the conspiracy theories developed at the cultural borderlands, is a clear definition of the participants of conspiracy who often include the representatives of a neighboring country ("an alien neighbor"); such narratives resemble spy mania and are based on a clear division of the society into "friends" and "enemies". Depending on the point of view, "friends" and "enemies" could equally become the internal enemies of the Empire. We can support this hypothesis referring to the materials of Volhynian Governorate's public life at the beginning of the $19^{\text {th }}$ century.

However, we can make more specific conclusions about whether this approach is applicable to the cultural borderlands of the empires in general only after examining similar material collected "on the other side of the border". Therefore, we need to study the existing narratives about "the alien neighbor" in the borderland territory of the Austrian Empire, for example, to compare the mechanisms of the Polish conspiracy Opytov wrote about. This comparison will provide researchers with ample scope for analysis of conspiracy processes.

This study has examined socio-political processes in the Russian Empire, namely the relationship of the "center" and "outskirts", from the point of view of the development of conspiracy narratives about the Polish intrigue against Russian stateness. It has shown how a literary work was created on the basis of conspiracy narratives well-known for contemporaries. The article puts forward a version of the authorship of letters about the Volhynian revolution published in the magazine "Kievskaia Starina" in 1883.

\section{References}

Bakhturina A. Yu. The Russian Empire Outskirts: government control and national politics during the years of the First World War (1914-1917). Moscow, ROSSPEN Publ., 2004, 392 p. (In Russian)

Beauvois D. The Gordian knot of the Russian Empire. Power, the Polish gentry and people in the Right-bank Ukraine (1793-1914). Moscow, NLO Publ., 2014, 1008 p. (In Russian)

Bibershtayn Y. R. Myth about the Conspiracy: philosophers, masons, Jews, liberals and socialists as conspirators. St. Petersburg, Novikova Publishing House, 2010, 400 p. (In Russian)

Bobkov I. Borderlands' Ethics: transculture as a Belarusian experience. Perekrestki, 2005, no. 3-4, pp. 54-70. (In Russian)

Breskiy O., Breskaya O. From Transitology to the Borderlands Theory. Essays on the "Eastern Europe" concept deconstruction. Vilnius, Vilnius University Press, 2008, 336 p. (In Russian)

Dameshek L. M., Dameshek I. L. The "outskirts" notion. Typological similarities and differences. Okrainy Rossiiskoy imperii: instituty i biurokratiia XIX - nachala XX vekov. Irkutsk, [s. n.], 2015, pp. 6-29. (In Russian)

Dolbilov M. D. Polonophobia and the Russification policy in the Empire's northwestern region in the 1860s. Obraz vraga. Moscow, NLO Publ., 2005, pp. 127-174. (In Russian)

Dolbilov M., Miller A. Western outskirts of the Russian Empire. Moscow, NLO Publ., 2007, 608 p. (In Russian)

Follis K. S. Building Fortress Europe. The Polish-Ukrainian Frontier. Philadelphia, University of Pennsylvania Press, 2012, 296 p.

${ }^{36}$ More about Russov's literature activity see: Smirnov A. V. Russov, Stepan Vasilevich // Russian Biographical Dictionary. Petrograd, 1918. Vol. 17. P. 627-633. 
Holm-Hansen J. Three perspectives on the borderland: The case of northeast Poland and the regions across the border. Pogranicze: Studia Społeczne. Białystok, 2000, vol. 9, pp. 95-113.

Khlebnikov M. V. “Concpiracy theory”: sociocultural experience. Moscow, NLO Publ., 2012, 464 p. (In Russian)

Russov S. V. The ancient history of Volyn governorate, which serves as a continuation of the Primeval History of the Peoples of the Russian State, composed by Count Ioann Pototski. St. Petersburg, [s. n.], 1829, 32 p. (In Russian)

Russov S. V. Volyn Notes, created in Zhitomir. St. Peterburg, [s.n.], 1809, 226 p. (In Russian)

Smirnov A.V. Russov, Stepan Vasilevich. Russkii biograficheskii slovar'. Petrograd, Russkoe istoricheskoe obshchestvo, 1918, 17, pp.627-633. (In Russian)

Vul'f L. Inventing Eastern Europe: The Map of Civilization on the Mind of the Enlightenment. Moscow, NLO Publ., 2003, 560 p. (In Russian)

Zorin A. "Feeding the double-headed eagle...": Literature and state ideology in Russia in the last third of $18^{\text {th }}$ first third of $19^{\text {th }}$ century. Moscow, NLO Publ., 2001, 416 p. (In Russian)

Статья поступила в редакцию 23 февраля 2020 г.

Рекомендована в печать 8 июня 2020 г.

Received: February 23, 2020

Accepted: June 8, 2020 